Original Research Paper

\title{
Pemanfaatan Dasbor pada Pemantauan Data Transaksi Penjualan
}

\author{
Maria Olva ${ }^{1}$, Ririt Dwiputri Permatasari ${ }^{1}$, Sanusi ${ }^{2}$, Pratiwi Hendro Wahyudiono ${ }^{3}$, \\ Afdal Suganda ${ }^{4}$ \\ ${ }^{1}$ Program Studi Teknik Informatika. Fakultas Teknik, Universitas Ibnu Sina. Batam, \\ Indonesia. \\ ${ }^{2}$ Program Studi Teknik Industri. Fakultas Teknik, Universitas Ibnu Sina. Batam, \\ Indonesia. \\ ${ }^{3}$ Universitas Andalas, Indonesia. \\ ${ }^{4}$ PT. TEC Indonesia. Kepulauan Riau, Indonesia.
}

\section{Article History}

Received:

04.01 .2021

Revised:

19.03.2021

Accepted:

11.04 .2021

*Corresponding Author: Pratiwi Hendro Wahyudiono Email:

tiwisyair@gmail.com

This is an open access article, licensed under: $\mathrm{CC}-\mathrm{BY}-\mathrm{SA}$
Abstrak: Penelitian ini bertujuan untuk mengimplementasikan dasbor pada pemantauan data transaksi penjualan di PT. Prima Labeling. Data pada sistem diperoleh dari hasil aliran informasi pengolahan data penjualan dan aliran data informasi pemanfaatan dasbor pada pemantauan data transaksi transaksi penjualan pada PT. Prima Labeling. Model sistem yang digunakan adalah UML yang mana pengembangan sistem penelitian menggunakan metode OOAD. Sistem informasi dirancang berbasis situs web dengan menggunakan bahasa pemrograman PHP dan database MySQL. Teknik penelitian kualitatif, dengan mengumpulkan data-data dan informasi secara deskriptif. Hasil penelitian ini pengguna dapat mengelola transaksi dengan mudah sekaligus dapat melakukan memantau transaksi penjualan pada waktu yang sebenarnya sehingga mempermudah proses pengelolaan data dan transaksi penjualan pada PT. Prima Labeling.

Kata Kunci: Dasbor, Pemantauan, Transaksi Penjualan, UML, OOAD.

Utilization of the Dashboard in Monitoring Sales Transaction Data

Abstract: Objective of the research is to monitoring sales transaction data at PT. Prima Labeling by implemented a dashboard. Data on the system is obtained from the results of the sales data processing information flow and dashboard utilization information of data flow monitoring sales transaction data at PT. Prima Labeling. System model used is UML where the research system development uses the OOAD method. Information system is designed based on a website using the PHP programming language and MySQL database. Qualitative research techniques is applied by collecting data and information descriptively. Results of this research users can easily manage transactions as well as monitor sales transactions in real time, thus simplifying the process of data management and sales transactions at PT. Prima Labeling.

Keywords: Dashboard, Monitoring, OOAD, Sales Transactions, UML. 


\section{Pendahuluan}

Penyajian informasi dan pengolahan data bukanlah hal yang mudah, mengingat didalam suatu organisasi memiliki banyaknya informasi. Organisasi memerlukan sebuah alat atau sistem untuk mengelola informasi dan meyajikan data tersebut dalam bentuk yang efektif dan efisien. Sistem merupakan suatu kesatuan usaha yang terdiri dari bagian-bagian yang berkaitan satu sama lain yang berusaha mencapai suatu tujuan dalam suatu lingkungan kompleks, Manfaat dari penggunaan sistem bagi perusahaan antara lain dapat meningkatkan efisensi dan efektifitas secara akurat dan waktu sebenarnya. Sistem tersebut dapat disajikan dengan menggunakan tampilan dasbor [1].

Dasbor merupakan tampilan visual yang dapat menyajikan informasi penting yang dibutuhkan satu atau lebih tujuan, digabungkan dan diatur pada sebuah layar menjadi informasi yang dapat dilihat secara sekilas [2]. Tampilan visual yang akan penulis implementasikan ini mengandung pengertian bahwa penyajian informasi harus dirancang sebaik mungkin, sehingga mata manusia dapat menangkap secara cepat dan otak manusia dapat memahami maknanya secara benar. Untuk itu dasbor sangat cocok digunakan oleh sebuah lembaga ataupun perusahaan dalam hal penyajian informasi agar dapat disampaikan kepada orang-orang yang membutuhkan informasi tersebut. Pemantauan atau pemantauan merupakan bagian dari manajemen pembangunan yakni kegiatan mengamati atau meninjau kembali atau mempelajari serta mengawasi secara terus menerus atau berkala terhadap pelaksanaan program kegiatan yang akan berjalan. Pemantauan dilakukan dalam rangka pengendalian diberi pengertian juga sebagai suatu proses pemantauan dan penilaian rencana atas pencapaian tujuan dan sasaran yang telah ditetapkan, untuk kemudian diambil tindakan korektif bagi penyempurnaan dan pengembangan lebih lanjut [3] Sedangkan pengertian data adalah bahan utama dari pekerjaan manajemen informasi. Tanpa data pekerjaan informasi tidak akan pernah ada dan data bersifat fakta [4]. Pengertian penjualan adalah suatu aktivitas perusahaan yang utama dalam memperoleh pendapatan, baik untuk perusahaan besar maupun perusahaan kecil [5].

Admin penjualan seringkali mengalami kesulitan dalam melakukan pengelolaan data transkasi penjualan karena belum adanya sistem pemantauan. Setiap awal bulan admin penjualan melakukan perekapan data transaksi dengan cara mengurutkan satu persatu nomor invoice mulai dari awal bulan hingga akhir bulan untuk dijadikan daftar invoice pada buku penjualan. Daftar invoice ini merupakan data seluruh invoice yang telah masuk kedalam penjualan selama 1 bulan di PT. Prima Labeling yang harus ditulis secara manual oleh admin penjualan. Data invoice yang sudah terurut dan dicatat didalam buku penjualan kemudian di buat ke dalam bentuk softcopy yang dikelompokan sesuai dengan nama pelanggan. Karena proses ini juga dilakukan secara manual maka kemungkinan kesalahan bisa terjadi pada saat memasukkan data. Hal ini tentu saja dirasa kurang efektif dan efisien karena proses informasi tentang perkembagan penjualan laporan tidak bersifat waktu sebenarnya.

Untuk memecahkan masalah tersebut diusulkan untuk membangun sebuah sistem informasi dasbor pemantauan penjualan dimana pengguna hanya perlu menekan tombol informasi yang dibutuhkan dan langsung menampilkan data. Dengan bantuan sistem, informasi dapat dikelola dengan baik sehingga dapat menciptakan kinerja yang lebih optimal. Berdasarkan uraian masalah yang telah dijelaskan, maka perlu dibuat suatu sistem informasi yang dapat menyelesaikan semua permasalahan yang ada di PT. Prima Labeling saat ini. Dengan membangun sistem dasbor pemantauan transaksi penjualan diharapkan menjadi solusi guna mencapai efektivitas dan efisiensi.

\section{Teori Dasar}

\subsection{Metode Perancangan OOAD}

Metode perancangan perangkat lunak yang digunakan dalam penelitian ini adalah metode Object Oriented Analysis and Desain (OOAD). Metodologi Booch's Object Oriented Analysis and Design yang disingkat dengan OOAD, merupakan penggabungan tiga pendekatan, yaitu: Object Oriented Design (OOD), Object Oriented Analysis (OOA) dan Object Oriented Programming (OOP). Hubungan antara OOA, OOD dan OOP adalah hasil pemodelan atau pengumpulan obyek dari OOA akan digunakan oleh OOD dan hasil dari OOD akan digunakan sebagai blueprint untuk membangun sistem dengan menggunakan OOP [6]. Pada tahapan OOAD ini menggunakan fountain model atau model air mancur. Model air terjun ini merupkan diagram yang mengingatkan kita tentang fakta bahwa meskipun beberapa kegiatan siklus hidup tidak dapat dimulai sebelum yang lain (contoh, kita tidak dapat memulai pengkodean sebelum kita mulai merancang), ada banyak tumpang tindih dan penggabungan kegiatan di seluruh siklus perangkat lunak secara lengkap. 
Dalam model air mancur ini, air naik ke tingkat tertentu dan kemudian jatuh ke bawah, baik ke kolam di bawah atau masuk kembali pada tingkat menengah. Demikian pula, dalam pengembangan perangkat lunak objek-objek di mana aliran umum dari analisis melalui desain ke implementasi adalah berulang. iterasi atau siklus ini terjadi pada dua (atau ketiganya) fase luas ini yaitu analisis, desain dan konstruksi. Kolam di sini adalah repositori kelas. Pada Gambar 1 menguraikan karakteristik umum model air mancur ini menunjukkan bahwa ada tingkat penggabungan yang tinggi dalam fase analisis, desain, implementasi dan unit pengujian. Dengan demikian, metode air mancur dianggap pendekatan yang lebih cocok digunakan untuk proyek pembuatan sistem baru. Dibandingkan dengan metode SSAD, OOAD lebih mudah digunakan dalam pembangunan sistem karena perangkat lunak dapat dibangun dengan cepat. Tetapi salah satu kelemahan paling mendasar adalah sering kali pemrogramam berorientasi obyek digunakan untuk melakukan anlisisis terhadap fungsional sistem, sementara metode OOAD tidak berbasis pada fungsional system [7].

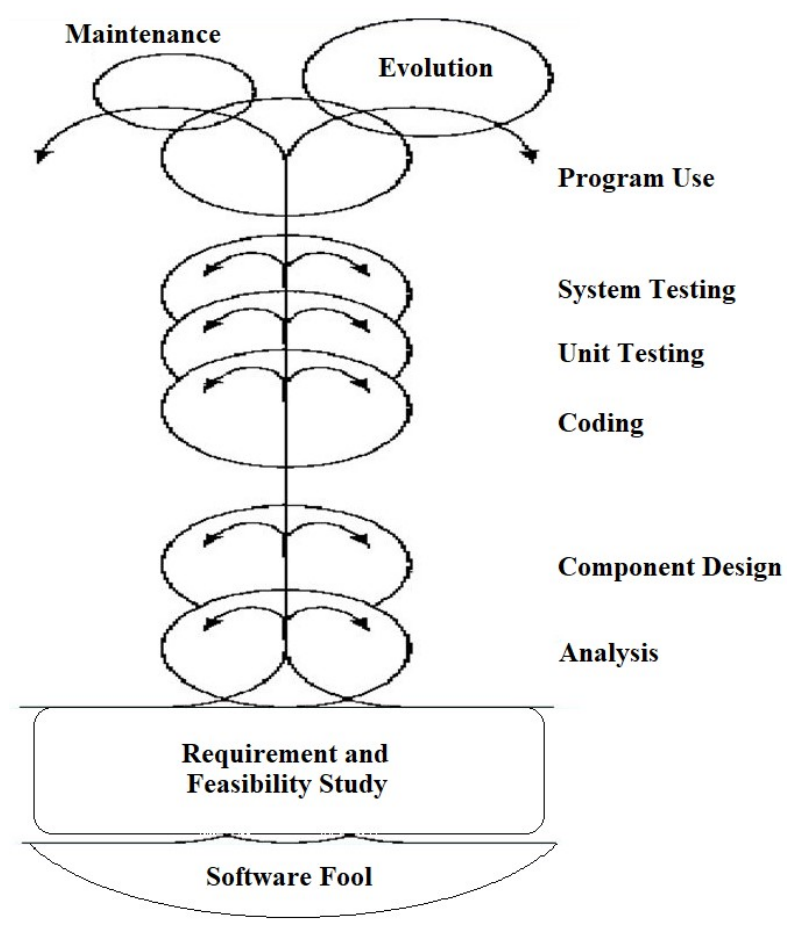

Gambar 1. Metode Air Mancur

\subsection{Tahap Kebutuhan}

Tahap Komunikasi (communication, yang terdiri atas Project Initiation dan Requirements Gathering) dilakukan sebelum memulai pekerjaan yang bersifat teknis. Hasil dari komunikasi tersebut adalah inisialisasi proyek, seperti menganalisis permasalahan yang dihadapi dan mengumpulkan data-data yang diperlukan, serta membantu mendefinisikan fitur dan fungsi perangkat lunak. Dari hasil observasi penulis kepada pihak PT. Prima Labeling, secara manajemen dan organisasi dirasakan sedikit permasalahan oleh pimpinan perusahaan, karena proses penanganan transaksi masih dilakukan secara manual dan belum adanya sistem untuk mengelola transaksi penjualan sehingga laporan tidak bersifat waktu sebenarnya. Maka penulis membutuhkan data aliran sistem informasi transaksi penjualan pada PT. Prima Labeling sebagai landasan untuk membagun sistem yang akan dibuat.

\subsection{Perancangan Sistem}

Perancangan sistem (Planning, yang meliputi Estimating, Scheduling, Tracking) merupakan tahap selanjutnya setelah analisa sistem, mendapatkan gambaran dengan jelas tentang apa yang dikerjakan 
pada analisa sistem, maka dilanjutkan dengan memikirkan bagaimana membentuk sistem tersebut. Perancangan sistem adalah suatu fase dimana diperlukan suatu keahlian perancangan untuk elemen-elemen komputer yang akan mengunakan sistem yaitu pemilihan peralatan dan program komputer untuk sistem yang baru. Perancangan adalah proses pengembangan spesifikasi baru berdasarkan rekomendasi hasil analisis sistem.

\subsection{Perancangan dan Pemodelan}

Tahapan perancangan dan permodelan arsitektur sistem (Modeling, yang meliputi Analysis \& Design) yang berfokus pada perancangan struktur data, arsitektur perangkat lunak, tampilan tatap muka, dan algoritma program. Tujuannya untuk lebih memahami gambaran besar dari apa yang akan dikerjakan. Perancangan prosedur system merupakan langkah dalam membuat rangkaian skema aplikasi mengacu pada prosedur yang ada dalam pemanfaatan dasbor sebagai pemantauan pada data penjualan PT. Prima Labeling, yaitu sebagai berikut:

\subsubsection{Perancangan Use Case}

Use case diagram yaitu diagram yang digunakan untuk menggambarkan hubungan antara sistem dengan aktor [8]. Diagram ini hanya menggambarkan secara global. Karena use case diagram hanya menggambarkan sistem secara global, maka elemen-elemen yang digunakan pun sangat sedikit. Berikut ini elemen-elemen yang digunakan pada use case diagram.

1. Sistem, merupakan batasan-batasan proses yang sudah dideskripsikn dalam sebuah sistem.

2. Aktor, elemen yang menjadi pemicu sistem. Aktor bisa berupa orang, mesin ataupun sistem lain yang berinteraksi dengan use case.

3. Use case, potongan proses yang merupakan bagian dari sistem.

4. Association, menggambarkan interaksi antara use case dan aktor.

5. Dependency, menggambarkan relasi (relationship) antara dua use case. Ada 2 (dua) tipe dari dependency yaitu, include dan extends.

6. Generalization, menggunakan pewarisan antara dua aktor atau use case dimana salah satu aktor atau use case mewarisi properties ke aktor use case yang satunya.

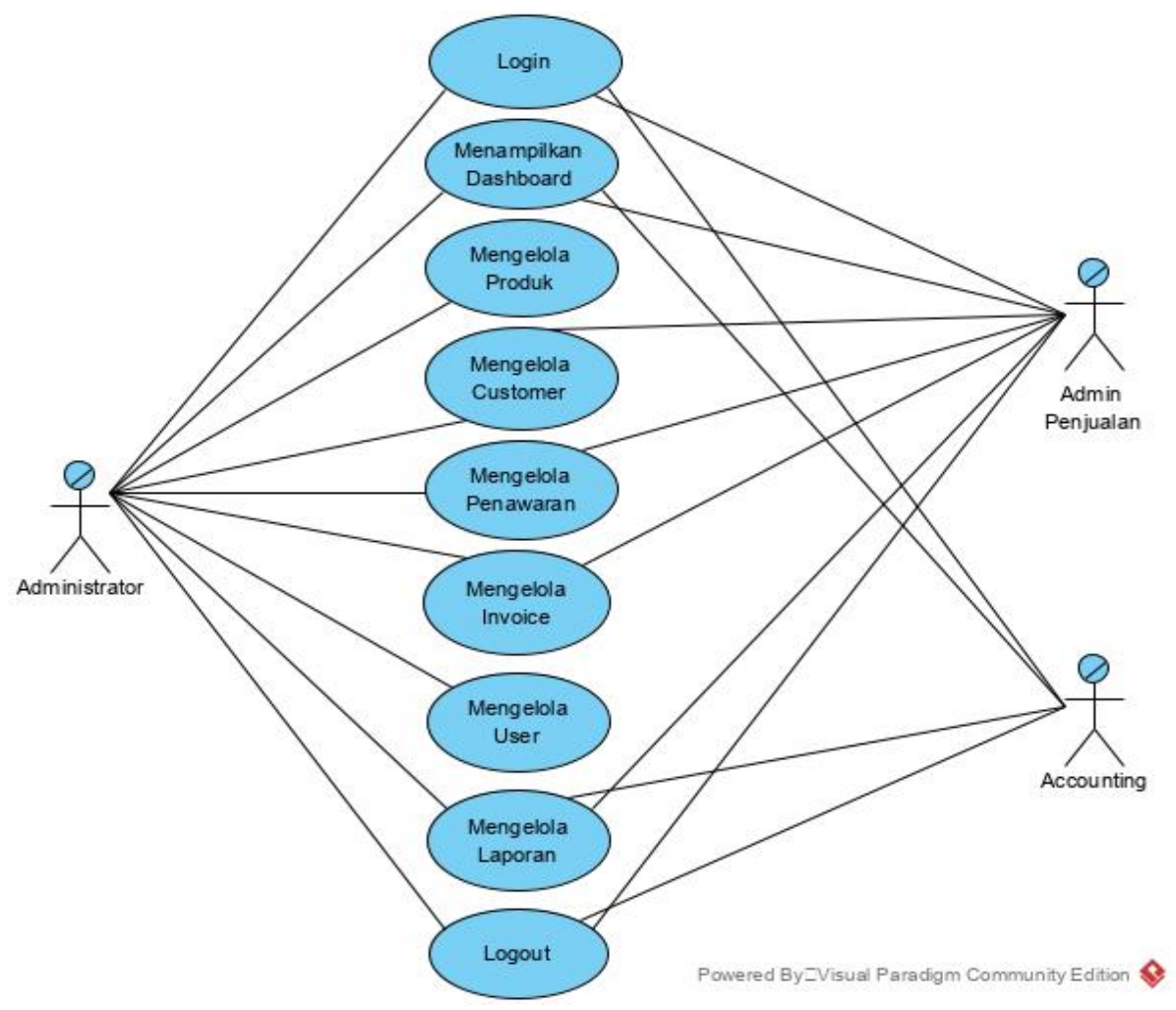

Gambar 2. Diagram: Use Case 
Deskripsi use case diagram adalah pemanfaatan dasbor sebagai pemantauan pada data penjualan dengan metode Object Oriented Analysis and Desain (OOAD), menggunakan bahasa pemrograman PHP Native pada PT. Prima Labeling. PHP singkatan dari PHP Hypertext yaitu bahasa pemrograman web server-side yang bersifat open source. PHP merupakan script yang terintegrasi dengan HTML dan berada pada server (server side HTML embedded scripting) [9].

\subsubsection{Perancangan Activity Diagram}

Activity diagram yaitu diagram yang digunakan untuk menggambarkan alur kerja (aktivitas) pada use case (proses), logika, proses bisnis dan hubungan antara aktor dengan alur-alur kerja use case [8].

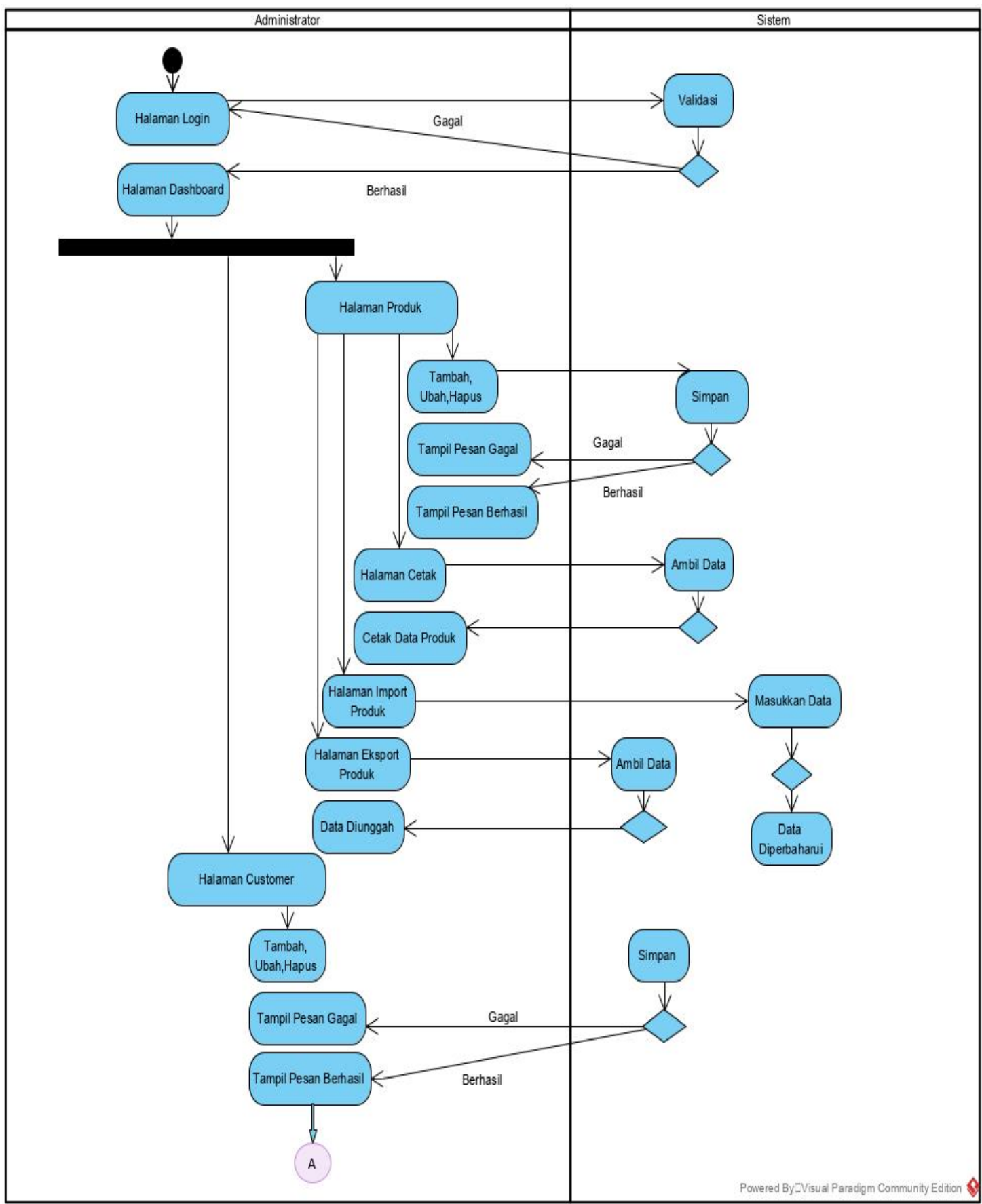

Gambar 3. Diagram Aktivitas: Administrator 
Pada tahap activity diagram digambarkan aliran aktivitas atau aliran kerja pada sistem. Dalam pemanfaatan dasbor sebagai pemantauan pada data penjualan PT. Prima Labeling activity diagram yang dibangun yaitu administrator, admin penjualan dan accounting. Gambar 3 adalah contoh rangkaian prosedur mengacu pada prosedur yang ada dalam sistem pemanfaatan dasbor sebagai pemantauan pada data penjualan pada PT. Prima Labeling pada Activity Diagram sebagai administrator.

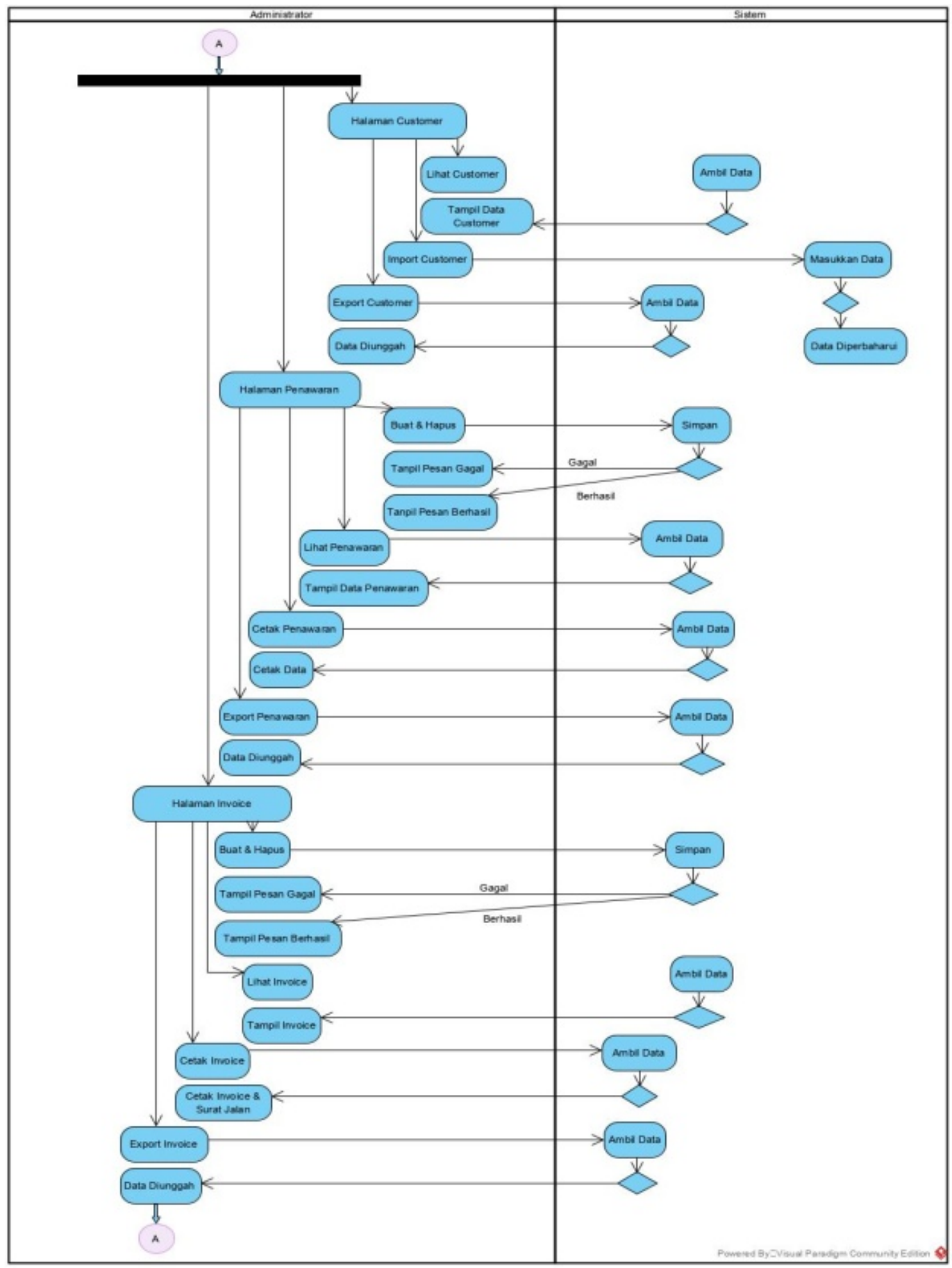

Gambar 4. Diagram Aktivitas: Administrator (lanjutan) 


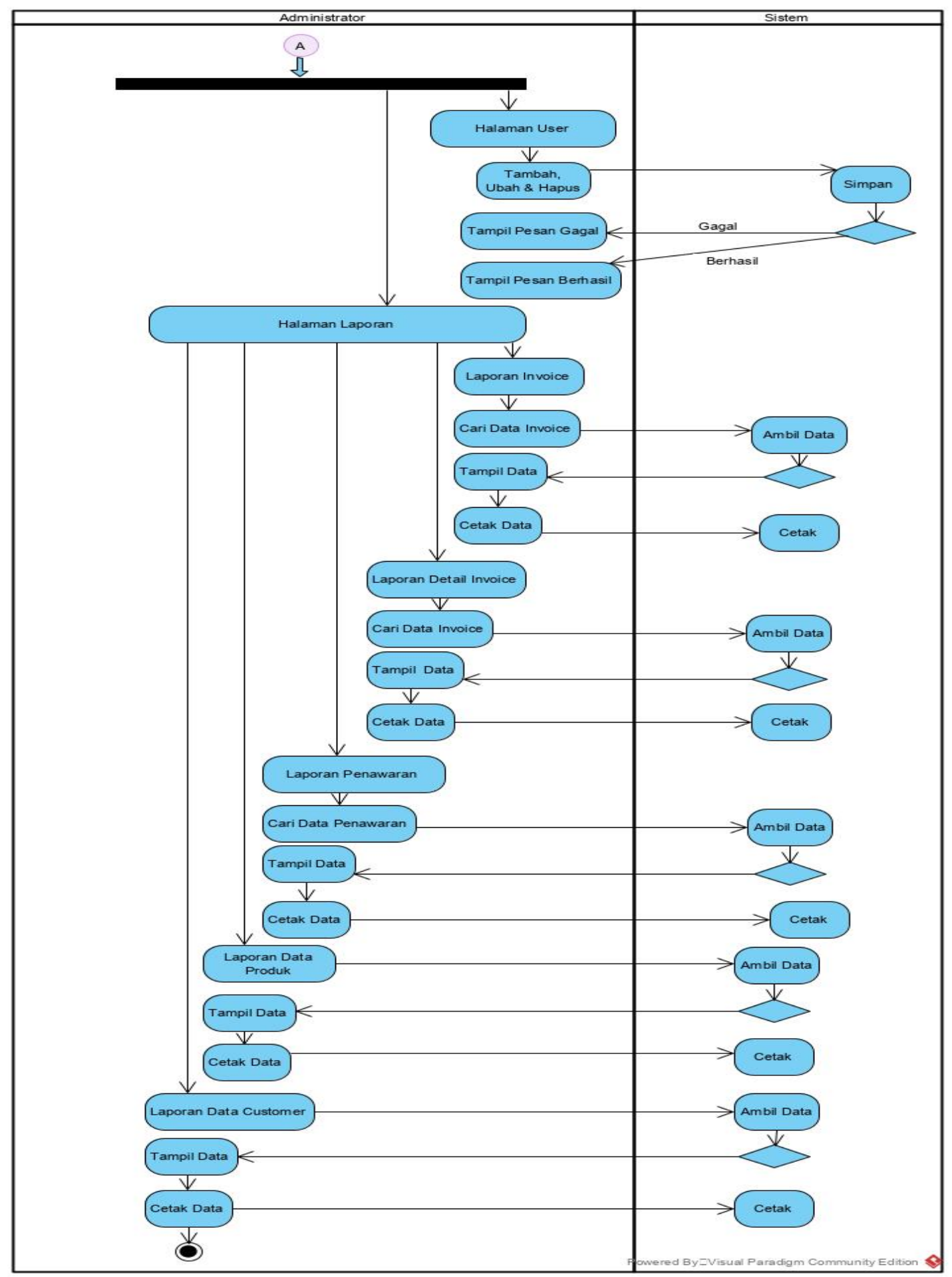

Gambar 5. Diagram Aktivitas: Administrator (lanjutan)

Berdasarkan Gambar 3, 4 dan 5 mendeskripsikan activity diagram administrator. Administrator melakukan login ke sistem melalui halaman login dengan memasukan username dan password, setelah itu sistem akan melakukan validasi terhadap akun yang dimasukkan. Apabila akun yang dimasukkan salah, maka akan kembali ke tampilan login dan muncul pesan kesalahan, dan jika akun yang dimasukan benar maka akan tampil ke halaman dasbor. Administrator dapat menjalankan semua menu dan hak akses pada sistem, seperti menambah, mengubah, melihat, mencetak, dan menghapus. Administrator dapat menambahakan, mengubah dan menghapus pengguna sistem. 


\subsubsection{Perancangan Sequence Diagram}

Sequence diagram menyatakan bahwa diagram sekuen menggambarkan obyek pada use case dengan mendeskripsikan waktu hidup obyek dengan pesan yang dikirimkan dan diterima antar obyek [8]. Diagram sekuensial atau sequence diagram adalah diagram interaksi yang digunakan untuk menunjukan aliran fungsionalitas dalam use case yang disusun berdasarkan urutan proses atau panggilan dan waktu.

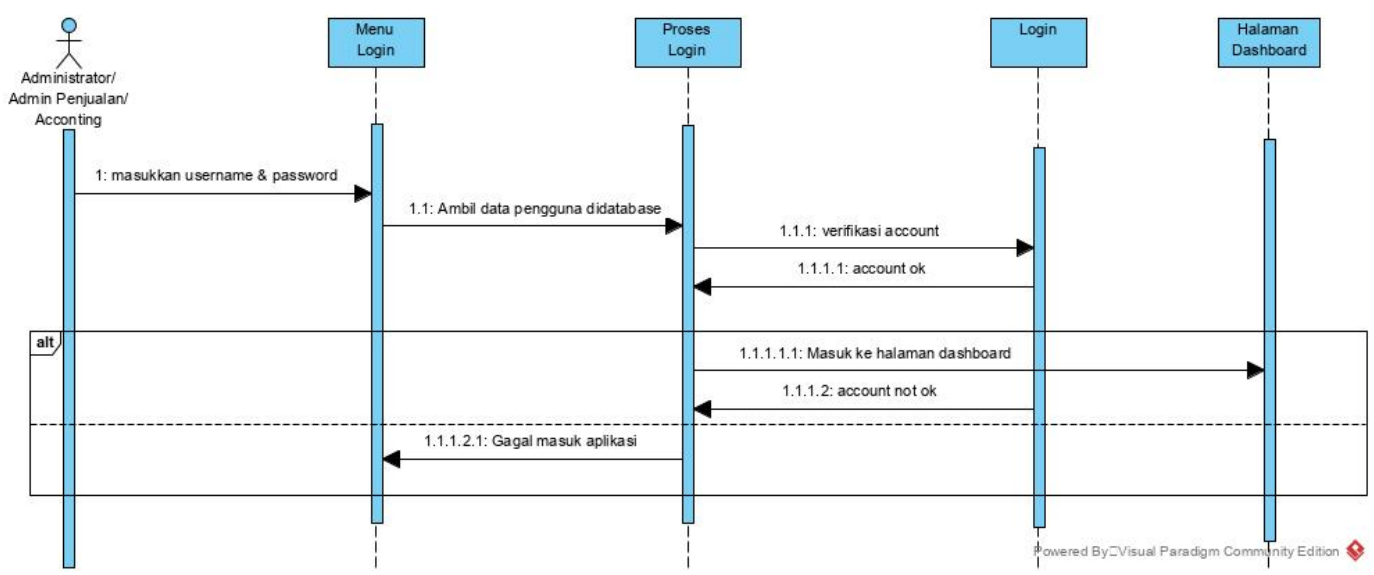

Gambar 6. Diagram Sequence: Login

Gambar 6 menjelaskan proses login dimana aktor yaitu administrator, admin penjualan dan Accounting memasukkan username dan password pada antarmuka login. lalu pada proses login, sistem akan memverifikasikan username dan password, jika username dan password sesuai dengan basis data maka aktor masuk ke menu utama, jika login gagal maka kembali memasukkan username dan password.

\subsubsection{Perancangan Class Diagram}

Class diagram menggambarkan struktur sistem dari segi pendefinisian kelas-kelas yang akan dibuat untuk membangun sistem. Kelas memiliki atribut dan method atau operasi. Atribut merupakan variabel variabel yang dimiliki oleh suatu kelas. Method atau operasi adalah fungsi-fungsi yang dimiliki oleh suatu kelas [8].

Gambar 7 merupakan class diagram yang terdapat pada pemanfaatan dasbor sebagai pemantauan pada data penjualan PT. Prima Labeling, yang terdiri dari antar muka yang dibutuhkan pada aplikasi, proses yang dibutuhkan dalam pembuatan aplikasi dan database yang dibutuhkan pada aplikasi, serta memperlihatkan hubungan antar antar muka, proses, dan database.

\subsubsection{Perancangan Antar Muka Sistem}

Sistem antarmuka adalah bagian dari suatu sistem informasi yang melibatkan masukan dan keluaran yang memerlukan intervensi manusia yang minimal. Antarmuka pemakai adalah suatu bagian dari suatu sistem informasi yang memerlukan interaksi pemakai untuk mencipta masukan dan keluran. Rancangan antaramuka baku adalah prinsip-prinsip dan aturanaturan umum yang harus diikuti bagi antarmuka dari sebarang sistem yang dikembangkan oleh organisasi [10]. Perancangan antar muka sistem bertujuan untuk menggambarkan sistem yang akan dibuat. Contoh perancangan antar muka sistem dapat dilihat pada Gambar 8. 


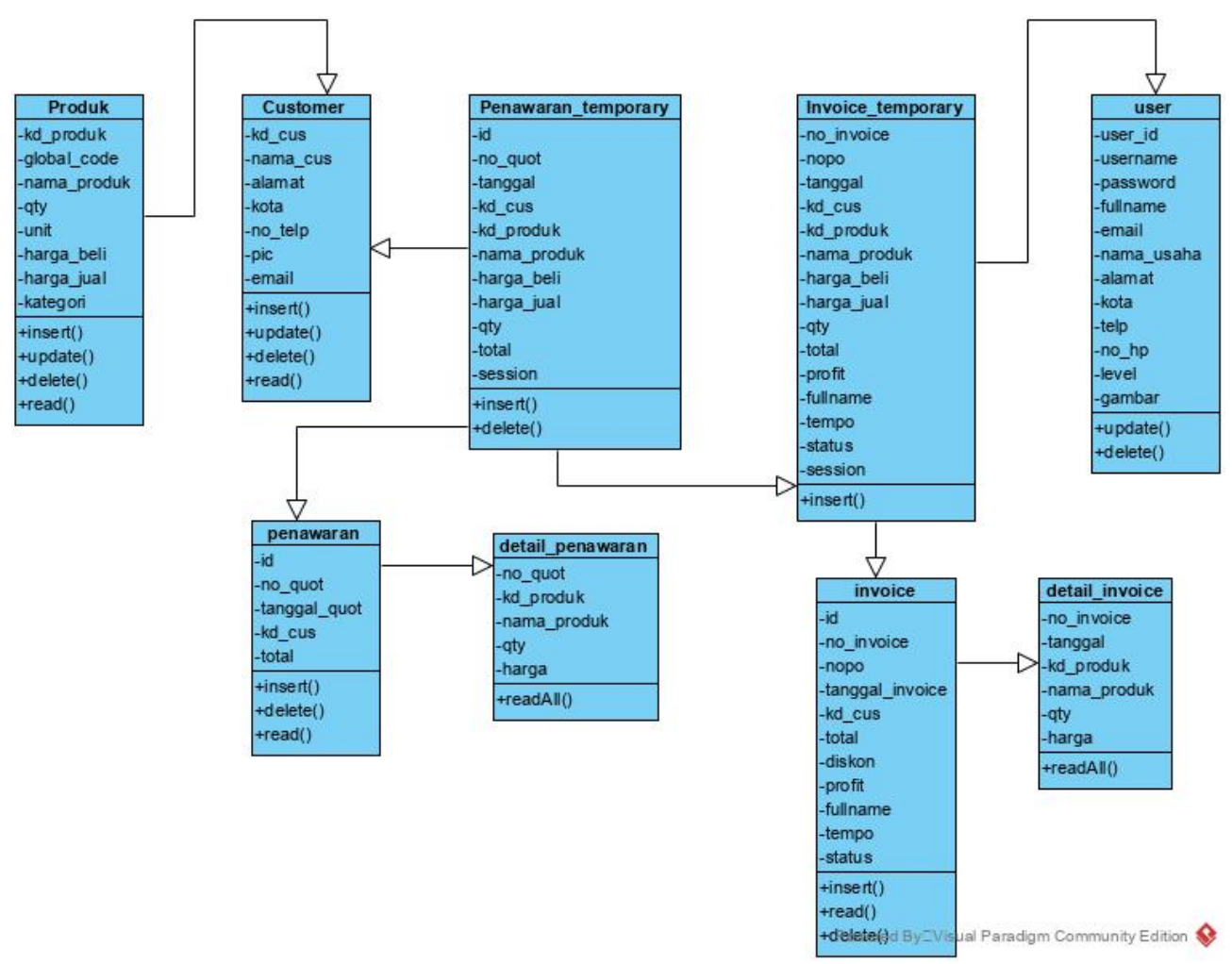

Gambar 7. Diagram Class

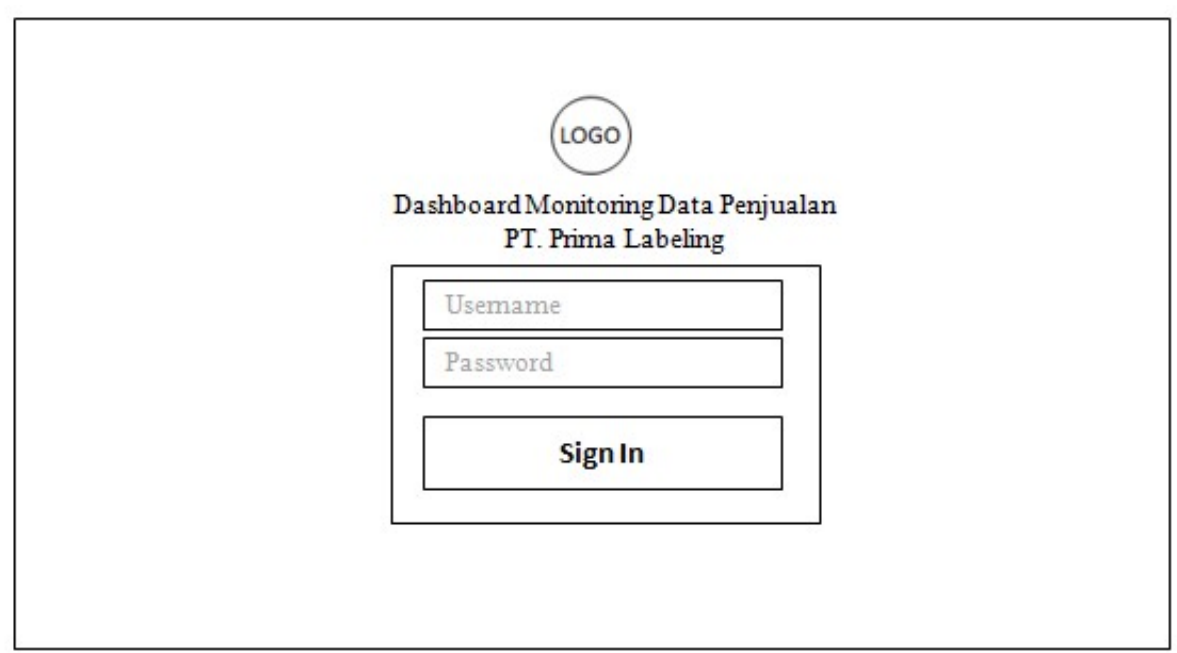

Gambar 8. Perancangan Antar Muka Menu Login

\subsubsection{Tahapan Kontruksi}

Tahapan konstruksi (Construction, meliputi Code \& Test) merupakan proses penerjemahan bentuk desain menjadi kode bentuk atau bahasa yang dapat dibaca oleh mesin. Setelah pengkodean selesai, dilakukan pengujian terhadap sistem dan juga kode yang sudah dibuat. Tujuannya untuk menemukan kesalahan yang mungkin terjadi untuk nantinya diperbaiki. Pengujian pada penelitian ini menggunakan pengujian Black Box yang berfokus pada persyaratan fungsional perangkat lunak. 
Tabel 1. Pengujian menggunakan Black Box

\begin{tabular}{|c|c|c|c|c|}
\hline No & Masukan & Proses & Keluaran & Catatan \\
\hline 1 & Halaman Login & $\begin{array}{l}\text { http://localhost/invo/index.ph } \\
\text { p }\end{array}$ & $\begin{array}{l}\text { Tampil halaman login sesuai } \\
\text { Pengguna }\end{array}$ & Sesuai \\
\hline 2 & $\begin{array}{l}\text { Halaman Utama } \\
\text { /dasbor }\end{array}$ & $\begin{array}{l}\text { http://localhost/invo/admin/in } \\
\text { dex.php }\end{array}$ & $\begin{array}{l}\text { Tampil halaman utama sesuai } \\
\text { pengguna }\end{array}$ & Sesuai \\
\hline 3 & Halaman Produk & $\begin{array}{l}\text { http://localhost/invo/admin/pr } \\
\text { oduk.php }\end{array}$ & $\begin{array}{l}\text { Tampil halaman menu produk } \\
\text { sesuai dengan hak akses } \\
\text { pengguna }\end{array}$ & Sesuai \\
\hline 4 & $\begin{array}{l}\text { Tambah Data } \\
\text { Produk }\end{array}$ & $\begin{array}{l}\text { http://localhost/invo/admin/in } \\
\text { put-produk.php }\end{array}$ & $\begin{array}{l}\text { Tambah Data produk sesuai } \\
\text { dengan hak akses pengguna }\end{array}$ & Sesuai \\
\hline 5 & import Data Produk & $\begin{array}{l}\text { http://localhost/invo/admin/pr } \\
\text { oduk_importxls.php }\end{array}$ & $\begin{array}{l}\text { import halaman menu Data } \\
\text { produk sesuai hak akses } \\
\text { pengguna }\end{array}$ & Sesuai \\
\hline 6 & Halaman Customer & $\begin{array}{l}\text { http://localhost/invo/admin/C } \\
\text { ustomer.php }\end{array}$ & $\begin{array}{l}\text { Tampil halaman menu } \\
\text { Customer sesuai dengan hak } \\
\text { akses pengguna. }\end{array}$ & Sesuai \\
\hline 7 & Tambah Customer & $\begin{array}{l}\text { http://localhost/invo/admin/in } \\
\text { put-Customer.php }\end{array}$ & $\begin{array}{l}\text { Tambah halaman menu data } \\
\text { Customer sesuai hak akses } \\
\text { pengguna }\end{array}$ & Sesuai \\
\hline 8 & $\begin{array}{l}\text { import Data } \\
\text { Customer }\end{array}$ & $\begin{array}{l}\text { http://localhost/invo/admin/C } \\
\text { ustomer_importxls.php }\end{array}$ & $\begin{array}{l}\text { import Data Customer sesuai } \\
\text { dengan hak akses pengguna }\end{array}$ & Sesuai \\
\hline 9 & $\begin{array}{l}\text { Halaman } \\
\text { Penawaran }\end{array}$ & $\begin{array}{l}\text { http://localhost/invo/admin/pe } \\
\text { nawaran.php }\end{array}$ & $\begin{array}{l}\text { Tampil halaman menu } \\
\text { penawaran sesuai hak akses } \\
\text { pengguna }\end{array}$ & Sesuai \\
\hline 10 & Data Penawaran & $\begin{array}{l}\text { http://localhost/invo/admin/da } \\
\text { ta-penawaran.php }\end{array}$ & $\begin{array}{l}\text { Tampil halaman menu data } \\
\text { penawaran sesuai hak akses } \\
\text { pengguna }\end{array}$ & Sesuai \\
\hline 11 & Halaman Invoice & $\begin{array}{l}\text { http://localhost/invo/admin/In } \\
\text { voice.php }\end{array}$ & $\begin{array}{l}\text { Tampil halaman menu } \\
\text { Invoice sesuai dengan hak } \\
\text { akses pengguna }\end{array}$ & Sesuai \\
\hline 12 & Data Invoice & $\begin{array}{l}\text { http://localhost/invo/admin/da } \\
\text { ta-Invoice.php }\end{array}$ & $\begin{array}{l}\text { Tampil halaman data Invoice } \\
\text { sesuai dengan hak akses } \\
\text { pengguna }\end{array}$ & Sesuai \\
\hline 13 & Halaman user & $\begin{array}{l}\text { http://localhost/invo/admin/us } \\
\text { er.php }\end{array}$ & $\begin{array}{l}\text { Tampil halaman menu data } \\
\text { user. }\end{array}$ & Sesuai \\
\hline 14 & Tambah user & $\begin{array}{l}\text { http://localhost/invo/admin/in } \\
\text { put-user.php }\end{array}$ & Tambah Data user & Sesuai \\
\hline 15 & Laporan Invoice & $\begin{array}{l}\text { http://localhost/invo/admin/la } \\
\text { poran-Invoice.php }\end{array}$ & $\begin{array}{l}\text { Tampil halaman menu } \\
\text { laporan data Invoice }\end{array}$ & Sesuai \\
\hline 16 & $\begin{array}{l}\text { Laporan Detail } \\
\text { Invoice }\end{array}$ & $\begin{array}{l}\text { http://localhost/invo/admin/la } \\
\text { poran-detail-Invoice.php }\end{array}$ & $\begin{array}{l}\text { Tampil halaman menu } \\
\text { laporan detail data Invoice }\end{array}$ & Sesuai \\
\hline 17 & Laporan Penawaran & $\begin{array}{l}\text { http://localhost/invo/admin/la } \\
\text { poran-penawaran.php }\end{array}$ & $\begin{array}{l}\text { Tampil halaman menu } \\
\text { laporan data penawaran }\end{array}$ & Sesuai \\
\hline 18 & $\begin{array}{l}\text { Laporan Data } \\
\text { Produk }\end{array}$ & $\begin{array}{l}\text { http://localhost/invo/admin/ce } \\
\text { tak-produk.php }\end{array}$ & $\begin{array}{l}\text { Tampil halaman menu } \\
\text { laporan data produk dan cetak }\end{array}$ & Sesuai \\
\hline 19 & $\begin{array}{l}\text { Laporan Data } \\
\text { Customer }\end{array}$ & $\begin{array}{l}\text { http://localhost/invo/admin/ce } \\
\text { tak-Customer.php }\end{array}$ & $\begin{array}{l}\text { Tampil halaman menu } \\
\text { laporan data Customer dan } \\
\text { cetak }\end{array}$ & Sesuai \\
\hline
\end{tabular}




\section{Implementasi}

Implementasi sistem merupakan tahap meletakan sistem sehingga siap dioperasikan. Implementasi bertujuan untuk mengkonfirmasi modul-modul perancangan sehingga pengguna bisa memberi masukan kepada pengembang sistem.

\subsection{Spesifikasi Perangkat Keras}

Perangkat keras yang digunakan dalam menjalankan aplikasi program ini menggunakan laptop Asus dengan processor Intel (R) Core (TM) i3 dengan spesifikasi seperti yang ditunjukkan pada Tabel 2.

Tabel 2. Spesifikasi Perangkat Keras

\begin{tabular}{|l|l|}
\hline Processor & Intel (R) Core (TM) i3 \\
\hline Memory & 4 GB (2.93 GB Usable) \\
\hline Hard Drive & 500 GB Sata \\
\hline Keyboard & StandardIV-38 \\
\hline Mouse & Standar \\
\hline Printer & Standar \\
\hline
\end{tabular}

\subsection{Spesifikasi Perangkat Lunak}

Perangkat lunak yang digunakan untuk mengimplementasikan sistem dapat dilihat pada Tabel 3.

Tabel 3. Spesifikasi Perangkat Lunak

\begin{tabular}{|c|l|l|}
\hline No & \multicolumn{1}{|c|}{ Spesifikasi } & \multicolumn{1}{|c|}{ Keterangan } \\
\hline 1 & Database & $5.0 .11-d e v-20120503$ \\
\hline 2 & Xampp & Versi 3.2.2 \\
\hline 3 & Program WEB & HTML,Javascript,PHP,CSS,Apache,PHP \\
\hline 4 & Software & Notepad++ \\
\hline 5 & Operating System & Windows 10 Pro 64-bit \\
\hline 6 & Web Browser & Google Chrome \\
\hline
\end{tabular}

\subsection{Perancangan Sistem Dasbor}

Perancangan sistem dapat disebut sebagai suatu tahapan pengambaran, perencanaan, dan pembuatan sketsa dari kumpulan elemen-elemen sistem yang menjadi suatu kesatuan utuh san mempunyai fungsi dan makna [11] [12] [13] [14]. Perancangan pemanfaatan dasbor sebagai pemantauan pada data penjualan PT. Prima Labeling adalah sebagai berikut:

a. Tampilan Menu Login

Halaman ini adalah halaman utama ketika pengguna membuka sistem pemanfaatan dasbor sebagai pemantauan pada data penjualan PT. Prima Labeling.

Berdasarkan Gambar 9 dapat dijelaskan tampilan menu login terdiri dari input username, password, dan tombol sign in berfungsi untuk masuk kedalam sistem. 


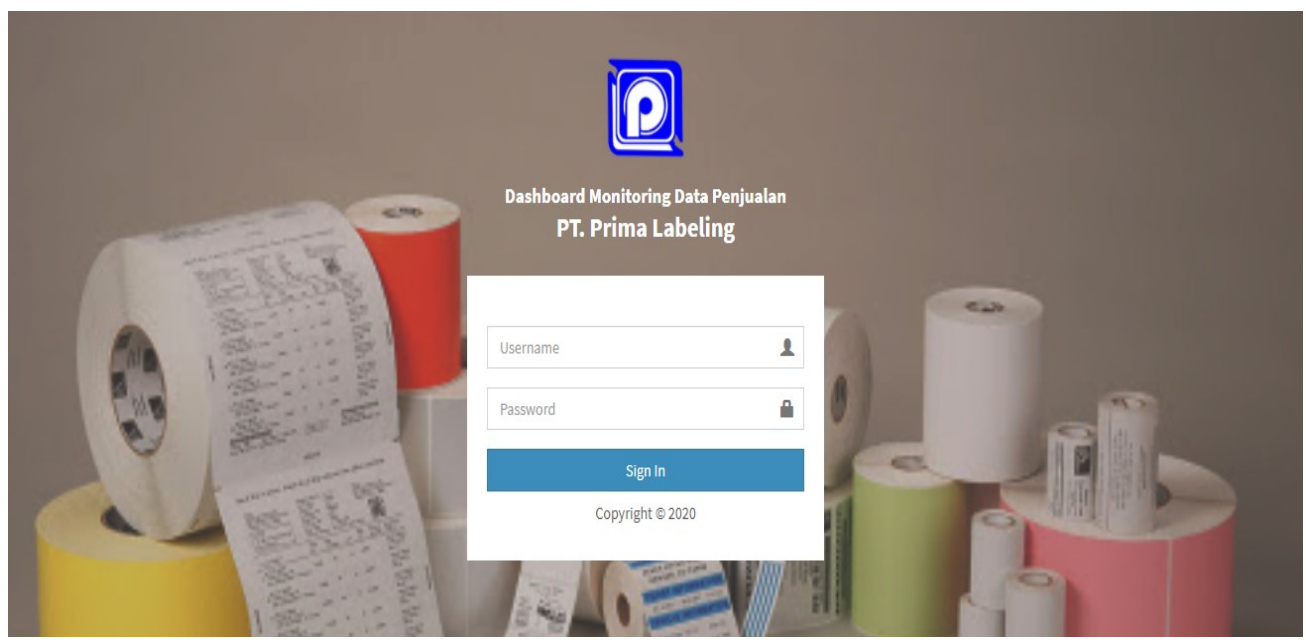

Gambar 9. Tampilan Menu Login

b. Tampilan Menu Utama

Dalam tampilan halaman utama administrator terdapat menu untuk mengelola data dan informasi pada sistem yaitu, menu produk, customer, penawaran, invoice, user dan laporan.

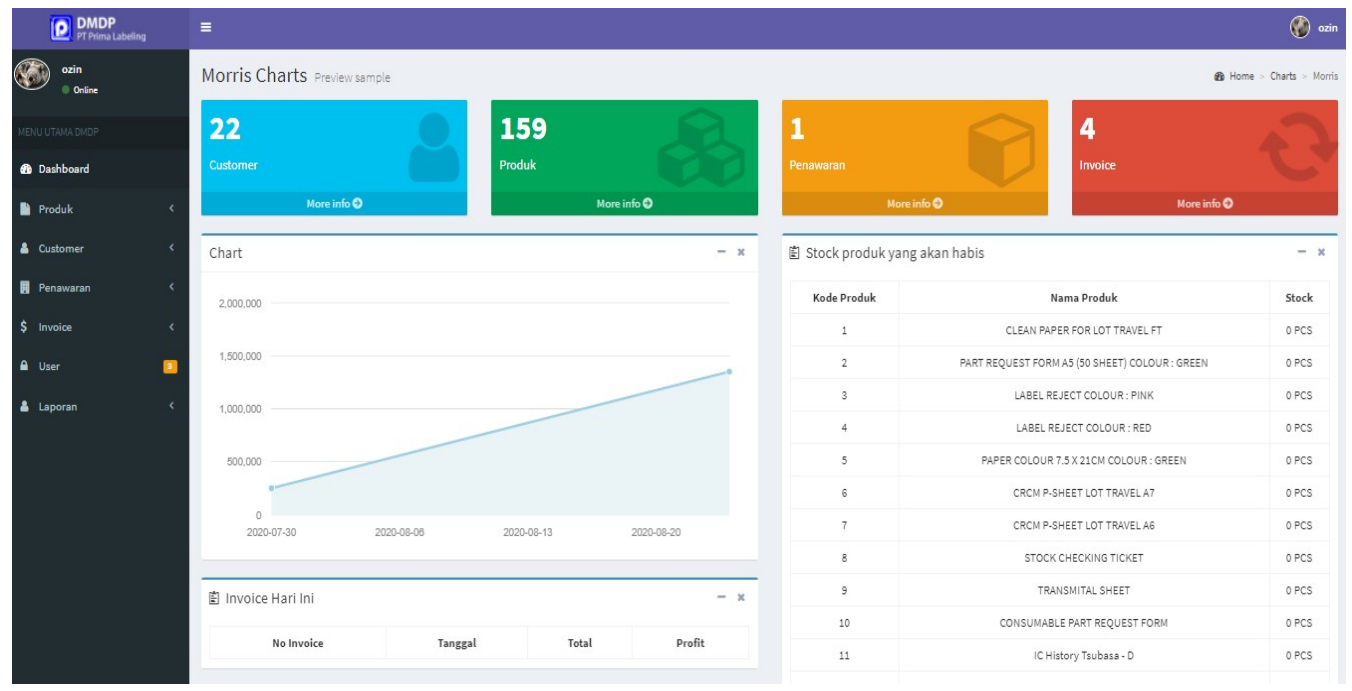

Gambar 10. Tampilan Halaman Utama / Dasbor

Berdasarkan Gambar 10 selain menu menampilkan menu utama, sistem juga menampilkan data dan informasi produk yang tersedia, pembaharuan invoice yang telah masuk (per hari) dan informasi mengenai data grafik penjualan secara waktu sebenarnya.

c. Tampilan Menu Produk

Tampilan halaman produk berisi tentang informasi mengenai data produk yang terdapat pada perusahaan.

Berdasarkan Gambar 11 dapat dijelaskan tampilan halaman data produk dimana pengguna dapat melakukan pengelolaan data produk sesuai dengan hak akses yang dimiliki di sistem pemanfaatan dasbor sebagai pemantauan data penjualan pada PT. Prima Labeling. 


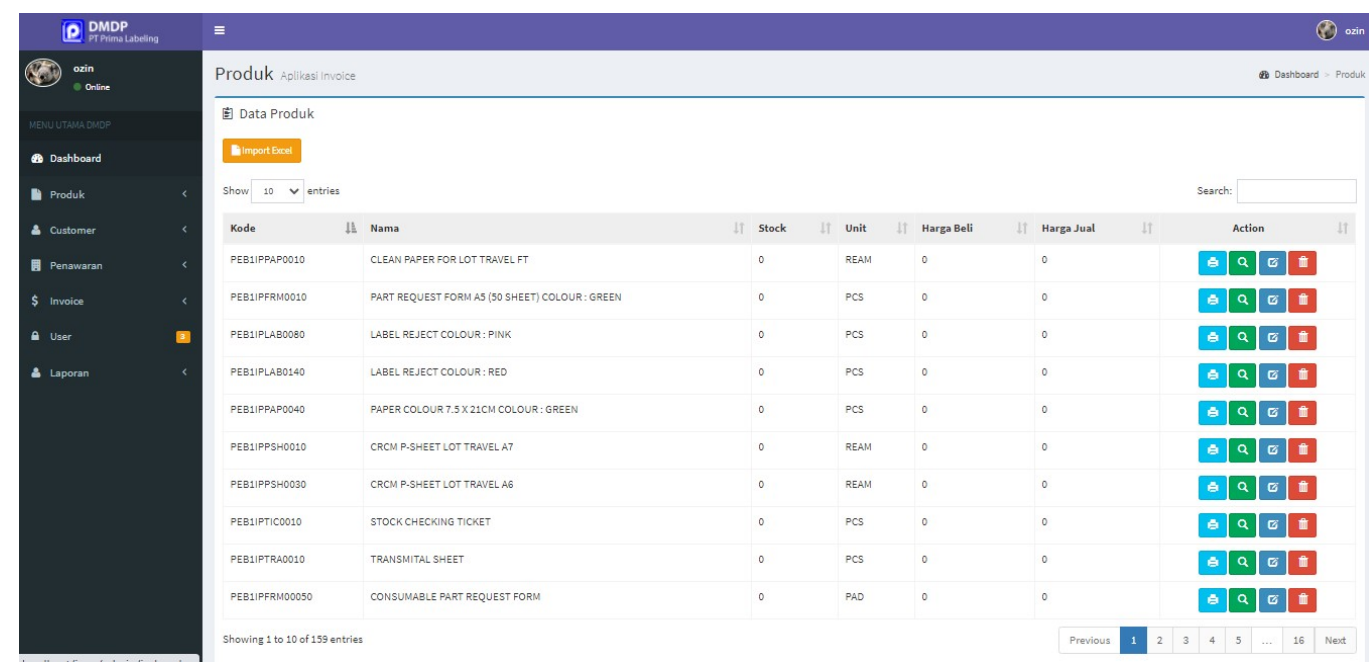

Gambar 11. Tampilan Menu Produk

d. Tampilan Halaman Customer

Tampilan halaman ini berisi data customer atau pelanggan perusahaan.

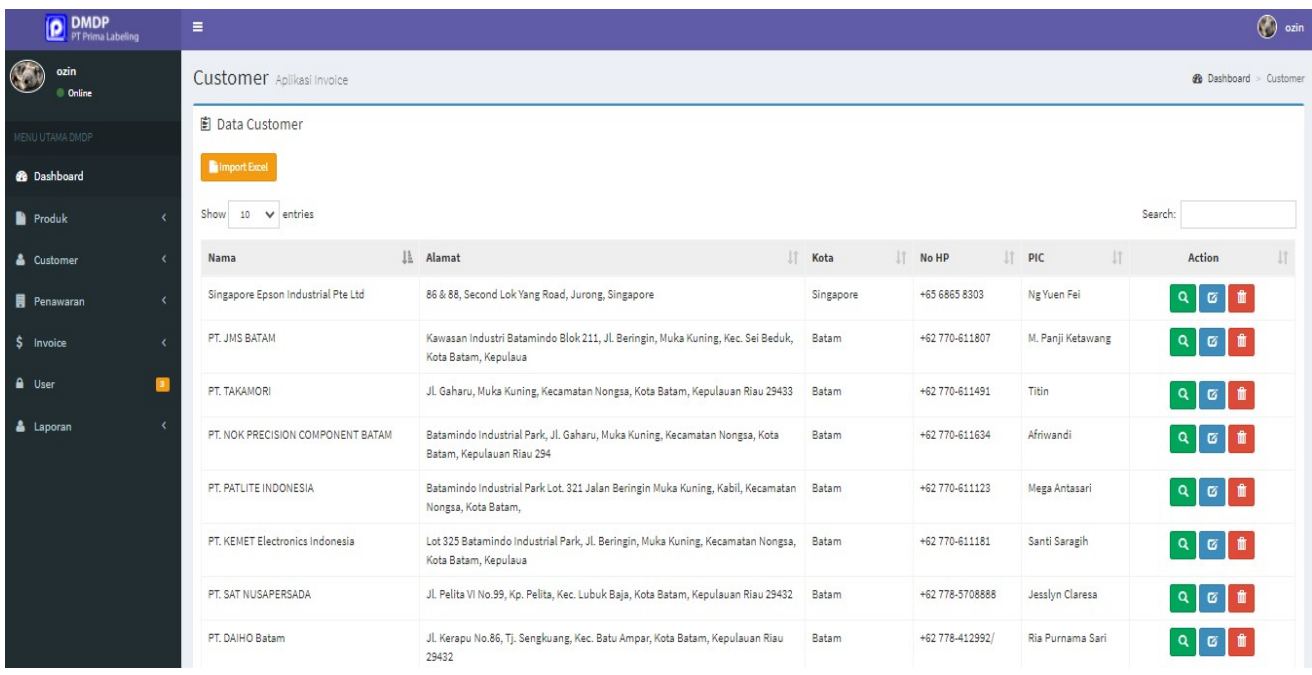

Gambar 12. Tampilan Menu Customer

Berdasarkan Gambar 12 halaman ini adalah halaman data customer dimana pengguna dapat melakukan pengelolaan data customer sesuai dengan hak akses yang dimiliki di sistem pemanfaatan dasbor sebagai pemantauan data penjualan pada PT. Prima Labeling.

\section{Pengujian}

Pengujian adalah proses dimana sistem di uji coba kelayakan dan kualitas dari perangkat lunak yang dibuat [15] [16]. Dalam pembuatan sistem penulis melakukan pengujian dengan metode Black Box. Pengujian Black Box berfokus pada persyaratan fungsional perangkat lunak. Dengan demikian, pengujian black box memungkinkan perekayasaan perangkat lunak mendapatkan serangkai kondisi input yang sesungguhnya semua persyaratan fungsional untuk suatu program. 


\subsection{Pengujian Black Box}

Pengujian Black Box berfokus pada persyaratan fungsional perangkat lunak. Pengujian sistem informasi ini menggunakan data uji berupa data input dari staff admin pada sistem yang telah dibuat. Berdasarkan rencana pengujian yang telah disusun, maka dapat dilakukan pengujian seperti yang ditunjukkan pada Tabel 4 dan Tabel 5.

Tabel 4. Pengujian Black Box Login Data Normal

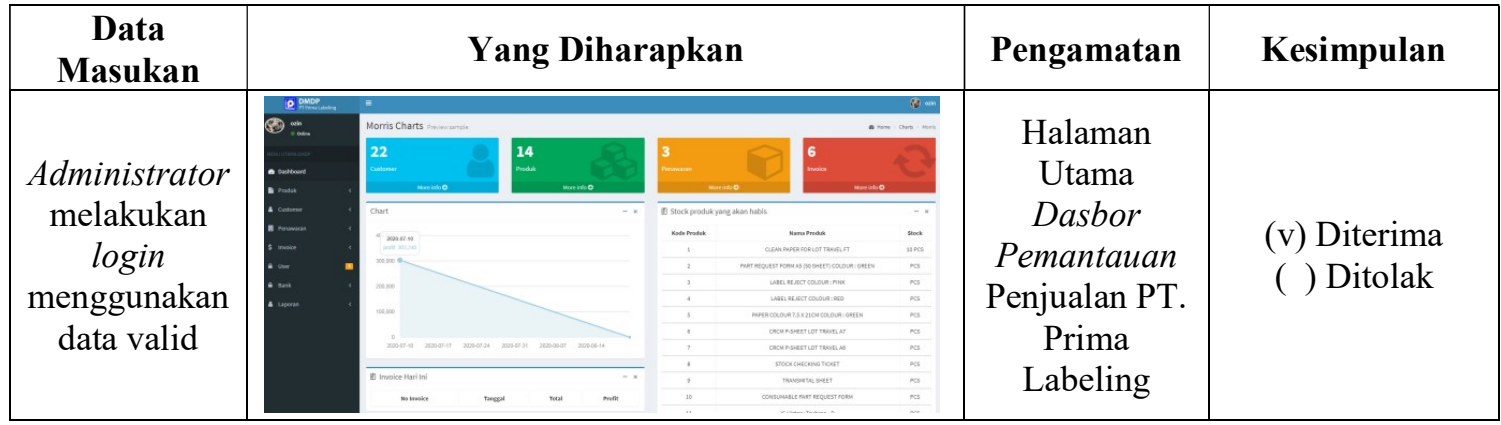

Tabel 5. Pengujian Black Box Login Data Gagal

\begin{tabular}{|c|c|c|c|}
\hline $\begin{array}{c}\text { Data } \\
\text { Masukan }\end{array}$ & Yang Diharapkan & Pengamatan & Kesimpulan \\
\hline $\begin{array}{c}\text { Administrator } \\
\text { melakukan } \\
\text { login } \\
\text { menggunakan } \\
\text { data tidak } \\
\text { valid }\end{array}$ & $\begin{array}{c}\text { Halaman } \\
\text { Menu Login }\end{array}$ & $\begin{array}{c}\text { (v) Diterima } \\
\text { ( ) Ditolak }\end{array}$ \\
\hline \\
\hline
\end{tabular}

\section{Kesimpulan}

Berdasarkan pembahasan pada analisis, desain, implementasi dan pengujian yang telah dilakukan pada aplikasi Pemanfaatan dasbor Sebagai pemantauan Data Penjualan PT. Prima Labeling maka dapat ditarik kesimpulan yaitu: Aplikasi Pemanfaatan dasbor Sebagai pemantauan Data pada Penjualan PT. Prima Labeling menggunakan metode OOAD berhasil dibangun dengan baik, sehingga dapat memonitor dan mempercepat hasil laporan penjualan di PT. Prima Labeling.

Saran yang dapat diberikan peneliti yang ditujukan kepada PT Labeling adalah Perlunya pelatihan sebelum menggunakan Sistem dasbor Sebagai pemantauan pada Data Penjualan PT. Prima Labeling, Menambahkan fitur tampilan diagram agar dapat menampilkan laporan penjualan dalam periode per tahun, dan Menambahkan fitur untuk penambahan produk baru pada menu penawaran di aplikasi Pemanfaatan dasbor Sebagai pemantauan pada Data Penjualan PT. Prima Labeling.

\section{Daftar Pustaka}

[1] Marimin, Sistem Informasi Manajemen Sumber Daya Manusia. Jakarta: PT. Gramedia Widiasarana Indonesia, 2006.

[2] F. D. Putra, J. Riyanto, and A. F. Zulfikar, "Rancang Bangun Sistem Informasi Manajemen Aset pada Universitas Pamulang Berbasis WEB,"Journal of Engineering, Technology, and Applied Science, vol. 2, no.1 pp. 32-50, 2020. doi: 10.36079/lamintang.jetas-0201.93.

[3] H. Nurcholis, Perencanaan Partisipatif Pemerintah Daerah. Jakarta: Grasindo, 2009. 
[4] Z. Amsyah, Manajemen Sistem Informasi. Jakarta: PT. Gramedia Pustaka Utama, 2005.

[5] I. Wily, "Analisis dan Perancangan Sistem Penjualan Berbasis Web pada PT. Sarang Imitasi", Seminar Nasional Teknologi 2007 (SNT 2007), Yogyakarta: 24 November 2017. Hal D2-D3, 2007.

[6] A. Suganda, I. Y. Panessai, R. D. Permatasari, and Pratiwi, "Sistem Informasi Pemantauan Retribusi Pada Menara Telekomunikasi", International Journal of Education, Science, Technology, and Engineering, vol. 2, no. 2, pp. 97 - 111, 2019. doi: 10.36079/lamintang.ijeste0202.27

[7] A. Kahate, Object Oriented Analysis \& Design. New Delhi: The McGraw- Hill, 2004.

[8] A. Fatoni, Normalisa and A. F. Zulfikar, "Merancang Sistem Aplikasi Pendaftaran Kartu Kredit di Bank Panin Kantor Kas Permata Taman Palem," Journal of Engineering, Technology, and Applied Science, vol. 2, no. 1, pp. 59-85, 2020. doi: 10.36079/lamintang.jetas-0201.95.

[9] Anhar, Panduan menguasai PHP \& MySQL secara otodidak. Jakarta: Mediakita, 2010.

[10] C. Anwar, and J. Riyanto, "Perancangan Sistem Informasi Human Resources Development" Pada PT. Semacom Integrated. International Journal of Education, Science, Technology, and Engineering, vo. 2, no. 1, pp. 19 - 38, 2020. doi: 10.36079/lamintang.ijeste-0201.16

[11] Yulianti and Normalisa, "Implementasi Arsitektur Client-Server dan Model-View-Controller untuk Membangun Aplikasi Administrasi di SMK Averus Jakarta," Journal of Engineering, Technology, and Applied Science, vol. 2, no. 1, pp. 1-18, 2020. doi: 10.36079/lamintang.jetas0201.91

[12] L. Swastina and A. S. Riadi, "Implementation of Feeder System to Support Monitoring the Potential Malnutrition ", ijeste, vol. 3, no. 2, pp. 48-59, Dec. 2020.

[13] N. H. Hasbullah and N. A. Z. Mohd Noor, "Sistem Temujanji Interaktif Berasaskan WEB", Journal of Engineering, Technology, and Applied Science, vol. 2, no. 3, pp. 110-117, Dec. 2020.

[14] N. F. Z. Zakaria, Z. Zainal Abidin, M. A. Abdullah Zawawi, and S. N. Shuhada, "Bloodbuddy: a Tracking System for Blood Donor Using GPS", Journal of Engineering, Technology, and Applied Science, vol. 2, no. 2, pp. 86-102, Aug. 2020.

[15] D. Putra, J. Riyanto, and A. F. Zulfikar, "Rancang Bangun Sistem Informasi Manajemen Aset pada Universitas Pamulang Berbasis WEB", Journal of Engineering, Technology, and Applied Science, vol. 2, no. 1, pp. 32-50, Apr. 2020.

[16] A. Fatoni, Normalisa, and A. F. Zulfikar, "Merancang Sistem Aplikasi Pendaftaran Kartu Kredit di Bank Panin Kantor Kas Permata Taman Palem”, Journal of Engineering, Technology, and Applied Science, vol. 2, no. 1, pp. 59-85, Apr. 2020. 